\title{
POLA PENALARAN PENGGALAN TEKS MATERI AJAR BAHASA INDONESIA DALAM BUKU SISWA KELAS VII KURIKULUM 2013
}

\author{
Liza Tri Handayani dan Laili Etika Rahmawati
}

Program Studi Pendidikan Bahasa Indonesia, Fakultas Keguruan dan Ilmu Pendidikan, Universitas Muhammadiyah Surakarta

lizatri.handayani@ymail.com

Laili.Rahmawati@ums.ac.id

\begin{abstract}
Abstrak
Proses menalar banyak digunakan dalam proses pembelajaran, karena dalam setiap proses belajar mengajar, siswa dan guru sama-sama berpikir dalam menentukan kebenaran. Bahkan, keduanya terdapat interaksi untuk saling bertukar pikiran. Melalui proses penalaran siswa menjadi paham mengenai suatu kebenaran. Namun, tidak jarang siswa tidak paham terhadap proses mencapai kebenaran itu sendiri, bahkan siswa tidak memahami adanya logika dalam suatu pembelajaran. Hal ini ditunjukkan saat siswa mengikuti tes potensi akademik (TPA) maupun tes IQ yang seringkali menggunakan kemampuan logika penalaran. Tujuan penelitian ini untuk mendeskripsikan pola penalaran penggalan teks materi ajar bahasa Indonesia dalam buku siswa kelas VII kurikulum 2013. Penelitian ini menggunakan jenis penelitian deskriptif eksplanatif. Data penelitian adalah materi ajar berupa penggalan teks materi ajar. Teknik analisis data menggunakan teknik analisis data mengalir model Miles dan Huberman. Hasil penelitian ini menunjukkan pola penalaran sesuai dengan tahap pendekatan saintifik. Pola penalaran yang terwujud yaitu proses menalar deduktif, analogi induktif, analogi deduktif, proses hubungan antar fenomena sebab-akibat, akibat-sebab, dan sebab-akibat 1-akibat 2. Muncul pola baru yaitu hubungan sebab-akibat 1-akibat 2-akibat 3, dan hubungan sebab-rangkaian akibat.
\end{abstract}

Kata Kunci: buku teks, kurikulum 2013, penalaran.

\begin{abstract}
s
Reasoning process is widely used in the learning process, because in each of the learning process, students and teachers alike to think in determining the truth. In fact, there is an interaction both for exchanging ideas. Through the process of reasoning students become aware of the truth. However, it is not uncommon someone does not understand the process of reaching the truth itself, even students do not understand if they are not introduced in a learning logic. This is demonstrated when students attend academic potential test (TPA) and IQ tests are often used logical reasoning ability. OBJECTIVE: To describe patterns of reasoning snippets of text Indonesian teaching materials in class VII curriculum guide, 2013. This research use descriptive research eksplanatif. The research data is the teaching materials teaching materials in the form of snippets of text. Data were analyzed using data analysis techniques flow model of Miles and Huberman. The results showed a pattern of reasoning in accordance with the scientific approach phase. The pattern of reasoning realized that the process of deductive reasoning, analogy inductive, deductive analogy, the relationship be-
\end{abstract}


tween causal phenomenon, due to the cause, and causal-effect 12. The new pattern appears that the causal relationship 1-induced second-result 3, and causal relationship-effects

Keywords: textbooks, curriculum 2013, reasoning.

\section{Pendahuluan}

Proses berpikir menjadi suatu hal penting dalam usaha memperoleh suatu pengetahuan. Menurut Suriasumantri (42:2010) berpikir merupakan suatu kegiatan untuk menemukan pengetahuan yang benar. Apa yang disebut benar bagi tiap orang tidak sama, maka oleh sebab itu kegiatan proses berpikir untuk menghasilkan pengetahuan yang benar itu pun juga berbeda-beda. Kebenaran terkadang muncul dari persepsi setiap orang, sehingga benar menurut si A, belum tentu benar menurut si B. Hal ini diperkuat oleh Suriasumantri (2010:42-43) bahwa dapat dikatakan tiap jalan pikiran mempunyai apa yang disebut sebagai kriteria kebenaran, dan kriteria kebenaran ini merupakan landasan bagi proses penemuan kebenaran tersebut. Hakikatnya, setiap manusia dianugerahi akal untuk berpikir, namun lain halnya dengan orang gila yang akalnya dapat dikatakan hilang, sehingga tidak mampu berpikir dengan baik dan benar. Manusia melakukan kegiatan sehari-hari dengan berpikir, meskipun terkadang seseorang mengartikan berpikir sama dengan proses belajar di bangku sekolah. Padahal, setiap kegiatan dalam kehidupan sehari-hari mencerminkan bahwa saat itu seseorang sedang berpikir untuk menemukan kebenaran. Misalnya seseorang ingin menggoreng ayam, yang digunakan tentu saja wajan penggorengan, bukan piring, hal-hal kecil seperti itu sudah dapat dikategorikan sebagai proses berpikir, yaitu penalaran.

Suriasumantri (2010:42) menyatakan bahwa penalaran merupakan suatu proses berpikir dalam menarik sesuatu kesimpulan yang berupa pengetahuan. Proses menalar banyak digunakan dalam proses pembelajaran, karena dalam setiap proses belajar mengajar, siswa dan guru sama-sama berpikir dalam menentukan kebenaran.
Bahkan, keduanya terdapat interaksi untuk saling bertukar pikiran, karena guru tidak selalu benar dan siswa tidak selalu salah. Melalui proses penalaran siswa menjadi paham mengenai suatu kebenaran, selain itu siswa juga paham terhadap proses untuk mengetahui kebenaran tersebut. Namun, tidak jarang seseorang tidak paham terhadap proses mencapai kebenaran itu sendiri, bahkan siswa tidak memahami jika mereka tidak diperkenalkan logika dalam suatu pembelajaran. Hal ini ditunjukkan saat siswa mengikuti tes potensi akademik (TPA) maupun tes IQ yang seringkali menggunakan kemampuan logika penalaran. Tidak jarang siswa kebingungan dengan tes-tes semacam itu, padahal setiap hari tanpa disadari, siswa belajar menalar, menganalogi, dan mencari hubungan antar fenomena setiap peristiwa. Hal semacam itu banyak dialami oleh siswa sekolah dasar (SD) dan siswa sekolah menengah pertama (SMP). Lain halnya yang dialami oleh siswa SMA atau SMK, kematangan pola berpikir mampu membuat siswa seumuran SMA lebih mampu memahami, bahkan dalam pelajaran bahasa Indonesia SMA memuat silogisme yang memang dipersiapkan untuk bekal masuk perguruan tinggi. Meskipun hanya sebagai dasar, silogisme begitu penting untuk diajarkan, selain itu agar siswa menjadi paham mengenai proses pemerolehan suatu kebenaran.

Silogisme termasuk lingkup kecil dalam proses berpikir, sehingga perlu adanya pengembangan muatan materi ajar mengenai silogisme secara lebih mendalam. Siswa juga berhak mengerti mengenai proses berpikir meskipun hanya sedikit dan belum seluas saat mempelajari penalaran di jenjang perguruan tinggi. Terlebih penerapan kurikulum 2013 mendatang memuat pendekatan saintifik dengan $5 \mathrm{M}$ yang ada di dalamnya, yaitu mengamati, menanya, menalar, mencoba, dan mengomunikasikan. 
Salah satu dari 5M adalah menalar, hal ini menunjukkan bahwa siswa dituntut untuk menalar dengan tepat dalam menentukan kebenaran. Berdasarkan pemikiran tersebut, peneliti tertarik untuk melakukan penelitian dengan judul "Pola Penalaran Penggalan Teks Materi Ajar Bahasa Indonesia dalam Buku Siswa Kelas VII Kurikulum 2013." Berdasarkan pemaparan di atas dapat dirumuskan masalah: bagaimana pola penalaran berdasarkan pendekatan saintifik penggalan teks materi ajar bahasa Indonesia dalam buku siswa kelas VII kurikulum 2013? Sesuai dengan rumusan masalah, maka tujuan penelitian ini adalah untuk memaparkan pola penalaran berdasarkan pendekatan saintifik penggalan teks materi ajar bahasa Indonesia dalam buku siswa kelas VII kurikulum 2013.

Penelitian ini menganalisis tentang pola penalaran penggalan teks materi ajar bahasa Indonesia dalam buku siswa kelas VII. Beberapa penelitian menjadi dasar untuk melakukan penelitian, hal ini menunjukkan bahwa penelitian yang akan dilakukan memiliki kesinambungan dengan penelitian sebelumnya. Hanya saja penelitian ini terfokus pada pola penalaran yang digunakan dalam penggalan teks materi ajar buku siswa.

Soleymanpour dan Kiadaliri (2014) dengan judul "Analysis Of Social Sciences Textbook in Fourth and Fifth Grade of Elementary Schools Based on Integrated Thinking Skills". Kesimpulan penelitian ini menunjukkan bahwa semua pelajaran yang bersifat sosial di dalam buku teks ilmu sosial kelas empat dan lima sekolah dasar, terdapat tingkat penerapan dan muatan komponen keterampilan berpikir untuk memperoleh informasi dan memusatkannya lebih banyak daripada keterampilan lainnya. Beberapa keterampilan lain menunjukkan bahwa tidak ada kecocokan dalam menerapkan kemampuan berpikir sesuai konten.

Febriani dan Rosyidi (2013) yang meneliti tentang "Identifikasi Penalaran Induktif Siswa dalam Memecahkan Masalah Matematika". Kesimpulan penelitian ini bahwa ketiga subjek (siswa yang memiliki nilai tinggi, sedang, dan rendah) menunjukkan langkah memahami masalah, mengelola data dan mencari pola dalam materi barisan bilangan bulat, namun cenderung tidak melakukan validasi dugaan. Untuk langkah menduga rumus dan generalisasi, ketiga siswa menunjukkan hasil yang berbeda. Siswa dengan nilai tinggi mampu menemukan hubungan yang ada pada barisan dan dapat menjelaskannya dengan menggunakan gambar dan dapat membuat generalisasi untuk masalah 1. Siswa dengan nilai sedang mampu menunjukkan hubungan yang berlaku namun tidak dapat menjelaskan dengan gambar dan tidak melakukan generalisasi. Siswa dengan nilai rendah tidak dapat menemukan pola yang berlaku untuk masalah 1 dan tidak melakukan generalisasi.

Penelitian berikutnya adalah penelitian yang dilakukan oleh Waldi, dkk. (2014) dengan judul "Analisis Penalaran Induktif dalam Karangan Argumentasi Siswa Kelas $X$ SMA Negeri 1 Linggo Sari Baganti Kabupaten Pesisir Selatan". Kesimpulan penelitian ini adalah jumlah semua data yang menggunakan penalaran secara induktif sebanyak 53 data. Setelah dilakukan analisis, data yang paling banyak ditemukan adalah data mengenai penalaran induktif dengan bentuk hubungan kausal sebanyak 34 paragraf, data dengan bentuk generalisasi sebanyak 18 paragraf, sedangkan data yang paling sedikit ditemukan adalah data dengan bentuk analogi sebanyak 1 paragraf. Dari analisis data tersebut dapat diketahui pemahaman siswa mengenai pengembangan paragraf secara induktif agak kurang, dari semua data yang dianalisis lebih banyak menggunakan pola pengembangan induktif dengan bentuk hubungan kausal dan generalisasi, sedangkan pola pengembangan dengan bentuk analogi masih jarang ditemukan. Jadi, pengembangan Penalaran Induktif dalam Karangan Argumentasi Siswa Kelas X SMA Negeri 1 Linggo Sari Baganti Kabupaten Pesisir Selatan didominasi oleh pola pengembangan dengan bentuk hubungan kausal. 
Penelitian terakhir yaitu penelitian yang dilakukan oleh Rizam (2015) dengan judul "Penalaran dalam Artikel Rubrik Opini Surat Kabar Harian Jawa Pos". Kesimpulan penelitian ini adalah penalaran dalam artikel rubrik opini Surat Kabar Harian Jawa Pos dilakukan dalam dua varian penalaran yaitu penalaran induktif dan deduktif. Penalaran induktif terdiri dari generalisasi, analogi, dan hubungan kausal. Generalisasi dalam artikel rubrik opini tersebut berupa generalisasi dengan loncatan induktif dan tanpa loncatan induktif. Hubungan kausal berlangsung dalam tiga varian yakni sebab-akibat, akibat-sebab, dan akibat-akibat. Penalaran deduktif dalam artikel rubrik opini Surat Kabar Harian Jawa Pos tidak dilakukan dalam bentuk silogisme lengkap, namun dilakukan dalam bentuk entimem. Silogisme tidak digunakan dalam artikel rubrik opini Surat Kabar Harian Jawa Pos ini disebabkan entimem dinilai lebih praktis, yakni hal yang dianggap telah dipahami tidak perlu dikemukakan lagi.

Penelitian-penelitian relevan di atas merupakan penelitian terdahulu yang pernah dilakukan oleh para ahli. Terdapat beberapa persamaan dan perbedaan dalam penelitian yang akan dilakukan. Persamaan penelitian-penelitian sebelumnya dengan penelitian yang akan dilakukan terlihat dari sumber data yang digunakan yaitu teks yang ada dalam buku teks, tetapi ada juga penelitian yang menganalisis penalaran yang digunakan dalam koran. Perbedaannya terlihat pada kekhususan pola penalaran yang dicari dalam data, banyak penelitian yang mencari kekhususan penelitian dalam penalaran induktif maupun deduktif. Selain itu terdapat penelitian relevan yang meneliti identifikasi penalaran induktif dalam memecahkan masalah, hal ini menunjukkan bahwa penalaran dapat memecahkan masalah untuk menemukan kebenaran.

Pengkajian dalam penelitian ini menggunakan beberapa teori yang saling berkaitan untuk dijadikan landasan dalam analisis dan pembahasan. Beberapa teori erat hubungannya dengan penelitian yang akan dilakukan, seperti teori mengenai buku teks dan buku siswa, materi ajar, dan proses penalaran. Sitepu (2012:17) menyatakan bahwa buku teks pelajaran yang kemudian disebut sebagai buku teks merupakan buku acuan wajib untuk digunakan di satuan pendidikan dasar dan menengah atau perguruan tinggi yang memuat materi pembelajaran dalam rangka peningkatan keimanan, ketakwaan, akhlak mulia, dan kepribadian, penguasaan ilmu pengetahuan dan teknologi, peningkatan kepekaan dan kemampuan estetis, peningkatan kemampuan kinestetis dan kesehatan yang disusun berdasarkan standar nasional pendidikan.

Kemendikbud (2013:ii) menyatakan bahwa buku siswa merupakan buku yang dipersiapkan Pemerintah dalam rangka implementasi kurikulum 2013. Buku siswa disusun dan ditelaah oleh berbagai pihak di bawah koordinasi Kementerian Pendidikan dan Kebudayaan, dan dipergunakan dalam tahap awal penerapan kurikulum 2013. Buku siswa menjabarkan usaha minimal yang harus dilakukan siswa untuk mencapai kompetensi yang diharapkan (Kemendikbud, 2013:iv). Buku teks maupun buku siswa memuat materi ajar. Menurut Ibrahim dan Sukmadinata (2003:100) materi pelajaran merupakan suatu yang disajikan oleh guru untuk diolah kemudian dipahami oleh siswa dalam rangka pencapaian tujuan-tujuan instruksional yang telah ditetapkan. Dengan kata lain, materi pelajaran merupakan salah satu unsur atau komponen yang penting artinya untuk mencapai tujuan-tujuan pengajaran. Materi pelajaran terdiri dari fakta-fakta, generalisasi, konsep, hukum atau aturan, dan sebagainya yang terkandung dalam mata pelajaran. Gulo (2008:9) menyatakan bahwa materi pelajaran dapat dibedakan antara materi formal dan materi informal. Materi formal adalah isi pelajaran yang terdapat dalam buku teks resmi (buku paket) di sekolah, sedangkan materi informal ialah bahan-bahan pelajaran yang bersumber dari lingkungan sekolah yang bersangkutan. Bahan-bahan yang bersifat informal ini dibutuhkan agar pengajaran itu lebih relevan dan aktual.

Jalaluddin (2013:109) menyatakan 
bahwa penalaran berarti berpikir dengan menggunakan nalar atau rasio. Sebagaimana dinyatakan oleh Suriasumantri (2010:42) bahwa penalaran merupakan suatu proses berpikir dalam menarik sesuatu kesimpulan yang berupa pengetahuan, sehingga penalaran merupakan kegiatan berpikir yang mempunyai karakteristik tertentu dalam menemukan kebenaran. Menurut Kurniasih dan Sani (2014:35) ada beberapa proses menalar, yaitu: proses menalar induktif yang merupakan cara menalar dengan menarik simpulan dari fenomena atau atribut-atribut khusus untuk hal-hal yang bersifat umum. Menalar induktif adalah proses penarikan simpulan dari kasus-kasus yang bersifat nyata secara individual atau spesifik menjadi simpulan yang bersifat umum. Kegiatan menalar secara induktif lebih banyak berpijak pada observasi inderawi atau pengalaman empirik. Proses menalar deduktif yang merupakan cara menalar dengan menarik simpulan dari pernyataan-pernyataan atau fenomena yang bersifat umum menuju pada hal yang bersifat khusus.

Pola penalaran deduktif dikenal dengan pola silogisme. Suriasumantri (2010:46) menyatakan bahwa logika atau penalaran induktif erat hubungannya dengan penarikan kesimpulan dari kasus-kasus individual nyata menjadi kesimpulan yang bersifat umum. Sedangkan di pihak lain logika deduktif membantu dalam menarik kesimpulan dari hal yang bersifat umum menjadi kasus yang bersifat individual (khusus). Penarikan kesimpulan secara deduktif biasanya mempergunakan pola berpikir yang dinamakan silogismus. Menurut Kurniasih dan Sani (2014:38-39) proses analogi terdiri dari dua jenis, yaitu analogi induktif dan analogi deduktif. Analogi induktif disusun berdasarkan persamaan yang ada pada dua fenomena atau gejala. Analogi deduktif merupakan suatu metode menalar untuk menjelaskan atau menegaskan suatu fenomena atau gejala yang belum dikenal atau masih samar, dengan sesuatu yang sudah dikenal atau masih samar, dengan sesuatu yang sudah dikenal. Lain halnya dengan Jalaluddin yang menyebut analogi sebagai analisis.
Menurut Jalaluddin (2013:115) analisis induktif merupakan perumusan umum mengenai suatu gejala dengan cara mempelajari kejadian-kejadian khusus yang berhubungan dengan hal itu. Analisis deduktif dinyatakan sebagai analisis yang digunakan untuk menetapkan kebenaran suatu pernyataan dengan menunjuk bahwa pernyataan lain yang telah ditetapkan kebenarannya. Penalaran juga dapat dilakukan melalui proses hubungan antar fenomena, sebagaimana yang dinyatakan oleh Kurniasih dan Sani (2014:39-40) terdiri dari hubungan sebab-akibat, hubungan akibat-sebab, dan hubungan sebab-akibat 1 - akibat 2 .

\section{Metode Penelitian}

Jenis dan desain penelitian yang digunakan pada penelitian ini adalah penelitian deskriptif kualitatif yang bersifat eksplanatif yang bertujuan untuk menggambarkan dan menjelaskan (to describe and to explain) (Sukmadinata, 2015:60). Peneliti memberikan deskripsi mengenai pola penalaran penggalan teks materi ajar dalam buku siswa kelas VII. Kemudian memberikan eksplanasi (kejelasan) tentang proses identifikasi wujud dan pola penalaran penggalan teks materi ajar bahasa Indonesia dalam buku siswa kelas VII kurikulum 2013. Data penelitian ini adalah semua materi ajar yaitu berupa penggalan teks materi ajar dalam buku siswa kelas VII kurikulum 2013. Sumber data yang digunakan untuk mendapatkan data-data tersebut adalah buku siswa kelas VII kurikulum 2013. Teknik pengumpulan data yang digunakan dalam penelitian ini adalah dokumentasi atau analisis dokumen, yaitu dokumen buku siswa kelas VII kurikulum 2013. Dokumen yang diteliti pada penelitian ini merupakan dokumen resmi yang dikeluarkan oleh Kemendikbud yaitu buku siswa kelas VII kurikulum 2013.

Analisis data menggunakan analisis data mengalir model Miles dan Huberman. Menurut Sugiyono (2010:337) analisis data dalam penelitian kualitatif dilakukan pada saat pengumpulan data berlangsung dan setelah selesai pengumpulan data da- 
lam periode tertentu. Miles dan Huberman (1994:10) dalam bukunya menyatakan bahwa secara garis besar analisis data kualitatif terdiri dari tiga aliran yang bersama-sama yaitu reduksi data, penyajian data, dan verifikasi. Kemudian menggali tema lebih dalam melalui buku dan memperoleh uraian secara keseluruhan. Aktivitas analisis data kualitatif dilakukan secara mengalir dan berlangsung terus menerus sampai tuntas, sehingga datanya sudah jenuh. Aktivitas dalam analisis data, yaitu reduksi data, penyajian data, dan verifikasi.

Langkah analisis data yang dilakukan pada penelitian ini yang pertama berdasarkan model Miles dan Huberman adalah (1) Reduksi data, mereduksi data pada materi ajar dalam buku siswa dilakukan dengan memfokuskan hal-hal penting yaitu mencari penggalan teks materi ajar yang memuat pola menalar induktif, deduktif, analogi induktif, deduktif, hubungan antar fenomena sebab-akibat, akibat-sebab, dan sebab-akibat 1-akibat 2. (2) Penyajian data, dalam penelitian kualitatif penyajian data bisa dilakukan dalam bentuk uraian singkat. Dalam hal ini Miles dan Huberman (dalam Sugiyono, 2010:341) menyatakan bahwa yang paling sering digunakan untuk menyajikan data dalam penelitian kualitatif adalah teks yang bersifat naratif. Data-data yang telah direduksi secara tidak sadar sekaligus dianalisis secara mendalam mengenai pola penalaran untuk mengungkap penalaran yang digunakan dalam suatu materi ajar berdasarkan konten isi materi. (3) Verifikasi, menurut Sugiyono (2010:345) kesimpulan awal yang dikemukakan masih bersifat sementara, dan akan berubah bila tidak ditemukan bukti-bukti yang kuat. Setelah display data secara bersama-sama sekaligus menarik kesimpulan atau verifikasi menge- nai kebenaran data yang telah melalui tahap reduksi data dan penyajian data. Verifikasi yang dilakukan dengan memilih data yang penting bahkan membuang data yang tidak dipakai, dan mengklasifikasikannya. Ketiga aliran tersebut dilakukan secara bersama-sama dan berlangsung terus menerus.

Untuk menguji validitas data, penelitian ini menggunakan trianggulasi data dan teori. Trianggulasi data atau sumber dilakukan dengan peninjauan ulang terhadap data atau sumber, yaitu meninjau ulang mengenai kesesuaian data yang digunakan yakni data materi ajar yang berupa teks dalam buku siswa kelas VII kurikulum 2013. Pada trianggulasi teori yaitu dengan peninjauan ulang terhadap teori-teori relevan yang digunakan dalam penelitian ini, sehingga ada kesesuaian antara teori dan data yang digunakan.

\section{Hasil Dan Pembahasan}

Pola penalaran dalam pendekatan saintifik diambil dari 5M, yaitu mengamati, menanya, menalar, mencoba, dan mengomunikasikan. Sebagaimana wujud proses pembelajaran dalam kurikulum 2013 yaitu dengan menggunakan pendekatan saintifik. Menalar menjadi proses yang sangat penting karena menggabungkan pikiran dengan fakta-fakta empiris. Dinyatakan oleh Kurniasih dan Sani (2014:35) bahwa penalaran merupakan proses berpikir logis dan sistematis atas fakta-fakta empiris yang dapat diobservasi untuk memperoleh simpulan berupa pengetahuan. Dalam proses memahami kebenaran dalam setiap teks materi ajar yang disajikan, terlebih dahulu siswa melakukan penalaran terhadap suatu kebenaran yang tampak dan memahami setiap frasa maupun klausa.

\section{a. Pola Menalar Deduktif}

\begin{tabular}{ll}
\hline No & Data \\
\hline 1) & Biota laut adalah seluruh makhluk hidup yang berkembang biak di laut. Biota laut yang \\
& ada di perairan Indonesia merupakan salah satu kekayaan Indonesia yang sangat berlimpah. \\
& Biota laut itu di antaranya terumbu karang, ikan, dan tumbuh-tumbuhan laut yang menjadi \\
& bagian dari ekosistem laut (Kemendikbud, 2013:21)..
\end{tabular}


2) Persoalannya adalah sebagian masyarakat belum menyadari pentingnya teknologi pengolahan sampah. Sekarang bergantung pada masyarakat apakah menjadikan sampah sebagai bahan yang kotor, berbau, menjijikkan, atau menjadikan sampah sebagai bahan yang bermanfaat bagi kehidupan (Kemendikbud, 2013:173).

3) Pesawat tersebut merupakan salah satu pesawat yang digunakan dalam dunia militer yang berfungsi sebagai pesawat pengintai. Tak hanya itu, fungsi pesawat ini juga digunakan untuk kegiatan memantau hutan, pencurian ikan, atau memantau aktivitas gunung berapi yang dipantau dari atas (Kemendikbud, 2013:191).

Pola menalar deduktif hanya ada tiga data yang ditemukan dari beberapa teks yang dianalisis. Seperti yang dinyatakan Suriasumantri (2010:46) bahwa logika deduktif membantu dalam menarik kesimpulan dari hal yang bersifat umum menjadi kasus yang bersifat individual (khusus). Pola menalar berdasarkan pendekatan saintifik yang ada dalam penggalan teks laporan hasil observasi tersebut adalah proses menalar deduktif. Penggalan kalimat tersebut menunjukkan adanya pernyataan-pernyataan atau fenomena yang bersifat umum "Biota laut adalah seluruh makhluk hidup yang berkembang biak di laut" menuju pada hal yang bersifat khusus "Biota laut yang ada di perairan Indonesia merupakan salah satu kekayaan Indonesia yang sangat berlimpah. Biota laut itu di antaranya terumbu karang, ikan, dan tumbuh-tumbuhan laut yang menjadi bagian dari ekosistem laut."
Pola proses menalar deduktif diawali dengan pemaparan peryataan umum menuju pada fenomena yang bersifat khusus. Proses menalar dengan menggunakan penalaran deduktif hanya ada tiga pola. Jika dibandingkan dengan temuan pola penalaran lainnya, pola menalar deduktif lebih sedikit. Karena data yang digunakan hanya kalimat dan paragraf sehingga proses menalar deduktif jarang ditemukan. Sebenarnya membutuhkan beberapa paragraf untuk dapat menentukan pola melalui proses menalar deduktif. Sama dengan proses menalar induktif yang juga membutuhkan kalimat yang panjang atau beberapa paragraf untuk menentukan pola menalar yang digunakan. Bahkan, dari beberapa teks materi ajar yang dianalisis, tidak ada muatan nilai karakter dalam kalimat atau paragraf yang memiliki pola menalar induktif.

\section{b. Pola Proses Analogi Induktif}

\begin{tabular}{ll}
\hline No & \multicolumn{1}{c}{ Data } \\
\hline 1) & Pengagum Jacko itu mengaku mendapat literatur permodelan matematika yang dapat \\
menghitung dosis obat dalam darah. Awalnya, penelitian Oki hanya bisa menjelaskan \\
efek samping Demerol yang dikonsumsi Jacko. Akan tetapi, kemudian dia mendapat ru- \\
mus aman untuk menghitung dosis obat yang wajar dikonsumsi dalam darah (Kemend- \\
ikbud, 2013:199). \\
Oki berharap dirinya dapat menjadi ilmuwan muda yang mewakili Indonesia dalam In- \\
ternasional Conference Young Scientist ke-17 serta dapat mengharumkan nama bangsa \\
(Kemendikbud, 2013:199). \\
Ning, aku tak ingin orang-orang akan ikut bergunjing tentangmu, hanya karena kau me- \\
nemuiku di sini. Aku tak mau orang menjauhimu, bila mereka tahu kau pernah datang \\
mengunjungiku (Kemendikbud, 2013:146). \\
Karya ini diterjemahkan ke dalam beberapa bahasa. Di Amerika misalnya, terjemahan \\
novel ini sudah terjual lebih dari 4.000 eksemplar. Filmnya juga mendapat sambutan \\
hangat di luar negeri, di antaranya saat film ini diputar di Festival Berlin (Kemendikbud, \\
2013:125).
\end{tabular}

Menurut Jalaluddin (2013:115) analogi induktif atau analisis induktif se- bagai sebuah perumusan umum mengenai suatu gejala dengan cara mempelajari ke- 
jadian-kejadian khusus yang berhubungan dengan hal itu. Seperti pada contoh data 1, analisis induktif dilakukan dengan cara mempelajari rangkaian kegiatan khusus yang menyangkut proses pelaksanaan penelitian. Mulai dari peneliti mendapat literatur permodelan matematika yang dapat menghitung dosis obat dalam darah. Kemudian, fakta bahwa penelitian hanya menjelaskan efek samping Demerol yang dikonsumsi Jacko, sampai pada mendapatkan rumus aman untuk menghitung dosis obat yang wajar dikonsumsi dalam darah. Untuk menyimpulkan faktor penyebabnya didukung oleh analisis deduktif. Analisis deduktif didasarkan pada kebenaran pernyataan yang sudah ada atau pernyataan yang berdasarkan teori. Dalam penggalan teks yang dijadikan data, penggalan kalimat lainnya memuat beberapa kalimat dengan sejumlah informasi bahwa uji karya ilmiah tentang kematian tragis penyanyi legendaris itu dalam perhitungan matematika. Sehingga, dapat diperoleh perumusan umum bahwa berdasarkan perhitungan matematika itu dapat disimpulkan bahwa penyebab kematian Michael Jackson lebih kuat disebabkan karena overdosis. Gejala-gejala khusus yang ada dalam analisis induktif merupakan langkah-langkah yang dilakukan untuk menemukan rumus baru dan mendapatkan hasil penelitian yang lebih baik. Dengan memadukan antara induktif (data lapangan) dan deduktif(teoretis), proses analisis atau analogi dalam upaya menarik kesimpulan menjadi lebih akurat (Jalaluddin, 2013:116). Dengan demikian, proses analogi induktif atau bisa juga disebut sebagai analisis induktif adalah gejala-gejala khusus yang saling berhubungan untuk merumuskan suatu gejala secara umum yang didasarkan pada data-data di lapangan.

\section{c. Pola Proses Analogi Deduktif}

\begin{tabular}{ll}
\hline No & \multicolumn{1}{c}{ Data } \\
\hline 1) & Keunikan yang dimiliki Sriti yaitu tak adanya roda untuk lepas landas atau mendarat. \\
& Namun, untuk lepas landas pesawat ini menggunakan catapult take off yaitu sejenis \\
peluncur yang terbuat dari logam baja stainless yang cukup fleksibel karena bisa di- \\
bongkar pasang kapan pun. Untuk mendarat, pesawat ini menggunakan jaring yang \\
bersifat lentur dan berbahan kuat. Kelebihan unik lainnya dapat dibawa kemana-mana \\
karena Sriti dapat dibongkar pasang (Kemendikbud, 2013:192). \\
Dengan teknologi yang tepat, sampah yang tadinya sebagai barang buangan, kotor, \\
berbau, menimbulkan penyakit, dan mencemari lingkungan dapat menjadi barang \\
yang bisa dimanfaatkan dan memiliki nilai ekonomi tinggi. Sampah anorganik bisa \\
membantu mengembangkan industri daur ulang (recycling), sedangkan sampah or- \\
ganik dapat dimanfaatkan industri pengolah kompos menjadi pupuk organik dan juga \\
dapat diolah menjadi industri energi atau industri bahan bangunan (Kemendikbud, \\
2013:173). \\
Pada awalnya Tari Saman merupakan salah satu media untuk menyampaikan pesan \\
(dakwah). Tari Saman mengandung pendidikan keagamaan, sopan santun, kepahla- \\
wanan, kekompakan, dan kebersamaan (Kemendikbud, 2013:34). \\
3)
\end{tabular}

Analisis deduktif digunakan untuk menetapkan kebenaran suatu pernyataan dengan menunjuk bahwa pernyataan itu telah tercakup dalam pernyataan lain yang telah ditetapkan kebenarannya (Jalaluddin, 2013:115). Sehingga, ada proses menjelaskan suatu gejala yang masih sulit diidentifikasi melalui gejala yang sudah dikenal atau sudah diketahui kebenarannya. Pada contoh beberapa data terdapat juga beber- apa gejala yang masing-masing memiliki suatu gejala yang masih samar atau belum mampu diidentifikasi. Data 3 menjelaskan gejala yang masih samar yaitu "Pada awalnya Tari Saman merupakan salah satu media untuk menyampaikan pesan (dakwah)", dalam hal ini dakwah belum dijelaskan kebenaran dakwah seperti apa yang akan disampaikan. Kemudian menjadi lebih tegas dan jelas melalui gejala yang didasarkan pada 
kebenaran pernyataan bahwa pesan yang sebenarnya ingin disampaikan melalui gejala "Tari Saman mengandung pendidikan keagamaan, sopan santun, kepahlawanan, kekompakan, dan kebersamaan".

Pola analisis deduktif yang digunakan cukup beragam dan tersebar dalam beberapa teks yang ada dalam buku siswa kelas VII kurikulum 2013. Seringkali penggunaannya tidak secara berurutan, sedangkan data yang digunakan adalah kalimat atau paragraf yang disusun secara sistematis dan berurutan, maka tidak heran jika pola analisis deduktif yang ditemukan dalam bentuk kalimat sistematis hanya sedikit. Tidak menutup kemungkinan jika seluruh teks menggunakan pola analisis ini. Sama halnya dengan data 1 dan data 2 keduanya juga memuat gejala yang masih samar yang kemudian dijelaskan dengan gejala yang telah ditetapkan kebenarannya. Tampak pada data 2 bahwa gejala masih samar mengenai nilai ekonomi tinggi yang tampak pada kalimat "Dengan teknologi yang tepat, sampah yang tadinya sebagai barang buangan, kotor, berbau, menimbulkan penyakit, dan mencemari lingkungan dapat menjadi barang yang bisa dimanfaatkan dan memiliki nilai ekonomi tinggi", dijelaskan dan dihubungkan dengan gejala yang nyata dan kebenarannya teruji, yaitu pada penggalan kalimat "Sampah anorganik bisa membantu mengembangkan industri daur ulang (recycling), sedangkan sampah organik dapat dimanfaatkan industri pengolah kompos menjadi pupuk organik dan juga dapat diolah menjadi industry energi atau industri bahan bangunan". Penjelasan tersebut mampu menjelaskan mengenai peluang mendapatkan nilai ekonomi dari sampah yang semula masih samar.

\section{d. Pola Proses Hubungan Antar fenomena Sebab-Akibat}

\begin{tabular}{ll}
\hline No & \multicolumn{1}{c}{ Data } \\
\hline 1$) \quad$ & Remaja adalah masa transisi dari masa anak-anak ke masa awal dewasa. Usia remaja \\
berada pada kisaran usia 10 tahun sampai dengan 21 tahun. Pada masa itu remaja \\
sedang mencari identitas dirinya. Oleh karena itu, remaja harus mendapatkan pendi- \\
dikan karakter agar dapat mengarahkan minatnya pada kegiatan-kegiatan positif (Ke- \\
mendikbud, 2013:61-62). \\
Sejak Ibu Bawang Putih meninggal, Ibu Bawang Merah kerap berkunjung ke tempat \\
tinggal Bawang Putih. Dia kerap membawakan makanan, menolong Bawang Putih \\
membereskan tempat tinggal atau cuma menemani Bawang Putih serta ayahnya men- \\
gobrol (Kemendikbud, 2013:153). \\
Dengan demikian, akibat kemacetan lalu lintas pun muncul, seperti waktu yang ter- \\
buang percuma. Selain itu, bahan bakar juga terbuang percuma. Kemacetan lalu lintas \\
juga dapat menyebabkan polusi udara dan suara. Bahkan, dapat mengakibatkan stress \\
yang menyerang kesehatan rohani kita (Kemendikbud, 2013:198).
\end{tabular}

Hubungan sebab-akibat menurut Kurniasih dan Sani (2014:39) adalah hal-hal yang mengemukakan sebab terlebih dahulu, kemudian ditarik simpulan yang berupa akibat. Pola hubungan sebab-akibat adalah pola yang sering muncul dan digunakan dalam pola penalaran beragam teks materi ajar dalam buku siswa kurikulum 2013. Sebab itu sendiri merupakan suatu hal yang menimbulkan sesuatu, dan akibat adalah hasil dari suatu peristiwa maupun kejadian. Pola sebab-akibat lebih mudah diidentifikasi jika dibandingkan dengan pola yang lain.

Beberapa contoh pola sebab-akibat dalam suatu teks yaitu pada data 1, 2, dan 3. Data 1 semula dipaparkan sebuah sebab, yaitu "Remaja adalah masa transisi dari masa anak-anak ke masa awal dewasa. Usia remaja berada pada kisaran usia 10 tahun sampai dengan 21 tahun. Pada masa itu remaja sedang mencari identitas dirinya". Kemudian, ditarik kesimpulan berupa akibat yaitu "Oleh karena itu, remaja harus mendapatkan pendidikan karakter agar 
dapat mengarahkan minatnya pada kegiatan-kegiatan positif.". masa remaja adalah masa yang kritis dan berusaha mencari jati diri, sehingga akibat yang ditimbulkan dari sebab itu adalah perlunya pendidikan karakter yang mampu mengarahkan remaja menuju arah positif. Sama halnya dengan data 2, hal yang menjadi sebab pada penggalan teks cerita pendek tersebut adalah "Sejak Ibu Bawang Putih meninggal", kemudian ditarik kesimpulan yang berupa akibat yaitu "Ibu Bawang Merah kerap berkunjung ke tempat tinggal Bawang $\mathrm{Pu}-$ tih. Dia kerap membawakan makanan, me- nolong Bawang Putih membereskan tempat tinggal atau cuma menemani Bawang Putih serta ayahnya mengobrol”. Sehingga keduanya memiliki hubungan penalaran sebab-akibat. Ibu Bawang Putih yang sudah meninggal menjadi sebab Ibu Bawang Merah terus berkunjung ke rumah Bawang Putih. Data 3, polanya yaitu sebab diungkapkan terlebih dahulu, kemudian akibat mengikuti di belakang. Sehingga, kesimpulan yang ada menjadi masuk akal, karena ada proses mengenai akibat itu sendiri yaitu dengan didahului sebab.

\section{e. Pola Proses Hubungan Antar fenomena Akibat-Sebab}

\begin{tabular}{ll}
\hline No & \multicolumn{1}{c}{ Data } \\
\hline 1) & $\begin{array}{l}\text { Aku lebih suka sendiri. Aku tak mau merepotkanmu. Karena suatu saat kau mungkin akan } \\
\text { menemui kesulitan hanya karena keberadaanku (Kemendikbud, 2013:146). }\end{array}$ \\
2) & $\begin{array}{l}\text { Penelitian yang mereka lakukan adalah mengelola limbah hewan yang terdapat pada kulit } \\
\text { udang dan kepiting yang mengandung bahan anti bakteri. Kedua siswa itu secara kreatif } \\
\text { memanfaatkannya untuk industri garmen (Kemendikbud, 2013:66). }\end{array}$ \\
3) & Tiba-tiba pintu terbuka dan laki-laki dengan perut gendut muncul. "Ooo.... Juragan. Silakan, \\
& Gan", sambut Pak Kerto sambil membungkuk (Kemendikbud, 2013:194). \\
\hline
\end{tabular}

Pola proses hubungan antar fenomena akibat-sebab merupakan kebalikan dari pola hubungan sebab-akibat. Sehingga, dalam pola hubungan ini akibat dipaparkan terlebih dahulu, kemudian sebab mengikuti di belakang. Tidak ada kekhususan dari pola ini terhadap pola sebab-akibat, karena hanya seperti bertukar posisi, sehingga tidak ada perbedaan khusus dari keduanya. Pola akibat-sebab tidak banyak ditemukan seperti pola sebab-akibat. Sebagaimana dalam suatu teks yang biasanya justru didominasi oleh proses menalar deduktif dibandingkan dengan induktif. Pola akibat-sebab tampak pada data 1, 2, dan 3 .

Akibat yang dikemukakan pada data 1 adalah "Aku lebih suka sendiri. Aku tak mau merepotkanmu", penyebab dari akibat tersebut yang kemudian menjadi simpulan yaitu "Karena suatu saat kau mungkin akan menemui kesulitan hanya karena keberadaanku". Sama halnya dengan data 2 akibat dinyatakan terlebih dahulu yaitu "Penelitian yang mereka lakukan adalah mengelola limbah hewan yang terdapat pada kulit udang dan kepiting yang mengandung bahan anti bakteri". Mengelola limbah hewan sebagai akibat dari kreativitas kedua siswa untuk memanfaatkan limbah yang berguna bagi industri garmen, simpulan yang menjadi penyebab, yaitu "Kedua siswa itu secara kreatif memanfaatkannya untuk industri garmen". Data 3 fenomena yang menjadi akibat diungkapkan pada kalimat "Tiba-tiba pintu terbuka", penyebab pintu terbuka ternyata diungkapkan melalui kalimat "laki-laki dengan perut gendut muncul, "Ooo.... Juragan. Silakan, Gan", sambut Pak Kerto sambil membungkuk". Jika dibandingkan dengan pola lainnya, baik pola proses menalar maupun analogi, pola hubungan antar fenomena lebih mudah digunakan, karena proses penalarannya tidak begitu rumit, sehingga siswa lebih mudah apabila menemukan teks dengan menggunakan pola penalaran akibat-sebab, sebab-akibat, maupun sebab-akibat 1-akibat 2 . Begitu pula data 2 yang sama-sama membentuk rangkaian hubungan antar fenomena sebab-akibat 1-akibat 2. 


\section{f. Pola Proses Hubungan Antar fenomena Sebab-Akibat 1-Akibat 2}

\begin{tabular}{ll}
\hline No & \multicolumn{1}{c}{ Data } \\
\hline 1) & Alam yang indah harus dicintai, dijaga, dan dilestarikan. Kecintaan pada alam itu harus \\
selalu kita tumbuhkan kepada seluruh warga Indonesia. Selain itu, rasa cinta itu juga ha- \\
rus terus ditanamkan agar alam Indonesia tetap menjadi paru-paru dunia yang bermanfaat \\
bagi kehidupan seluruh makhluk hidup yang hidup dari masa ke masa (Kemendikbud, \\
2013:5-6). \\
2) \\
Meredam erosi pada lahan pertanian terbuka dapat dilakukan dengan menutup tanah \\
Tangan plastik berlubang. Dengan demikian, air hujan tidak langsung menggerus tanah. \\
cepat pertumbuhannya (Kemendikbud, 2013:201). \\
Nenek itu menyimpan baju Bawang Putih yang hanyut. Dia mau menyerahkan baju itu \\
jika Bawang Putih mau membantunya membersihkan rumah. Bawang Putih pun segera \\
membantu nenek membersihkan rumah (Kemendikbud, 2013:153).
\end{tabular}

Proses hubungan antar fenomena sebab-akibat 1-akibat 2 adalah penyebab yang ada mampu menimbulkan serangkaian akibat, akibat pertama kemudian menjadi penyebab dari akibat kedua, bahkan akibat kedua menjadi penyebab dari akibat ketiga, dan seterusnya (Kurniasih dan Sani, 2014:40). Pola seperti ini muncul pada kalimat atau paragraf yang panjang. Namun, tidak menutup kemungkinan ditemukan juga dalam kalimat atau paragraf yang pendek. Seperti pada data 3, satu penyebab yang menimbulkan rangkaian akibat adalah "Nenek itu menyimpan baju Bawang Putih yang hanyut", dari penyebab tersebut muncul akibat 1 yaitu "Dia mau menyerahkan baju itu jika Bawang Putih mau memban- tunya membersihkan rumah", akibat 1 menjadi penyebab akibat 2 . Akibat kedua yaitu "Bawang Putih pun segera membantu nenek membersihkan rumah". Ketiganya saling membentuk serangkaian akibat. Sama halnya dengan data 1 , yang menjadi penyebab pada penggalan teks tersebut adalah "Alam yang indah harus dicintai, dijaga, dan dilestarikan. Kecintaan pada alam itu harus selalu kita tumbuhkan kepada seluruh warga Indonesia. Selain itu, rasa cinta itu juga harus terus ditanamkan". Akibat yang pertama yaitu "Alam Indonesia tetap menjadi paru-paru dunia", yang kemudian menjadi penyebab dari akibat kedua "yang bermanfaat bagi kehidupan seluruh makhluk hidup yang hidup dari masa ke masa".

\section{g. Pola Proses Hubungan Antar fenomena Sebab-Akibat 1-Akibat 2-Akibat 3}

\begin{tabular}{ll}
\hline No & \multicolumn{1}{c}{ Data } \\
\hline 1) & Tak jauh dari tempat kejadian, segerombolan Ulat Bulu melihat kejadian ini. Melihat \\
& kondisi burung merak yang tidak berdaya Ulat Bulu pun membantu Burung Merak untuk \\
& dibebaskan dan mereka pun menyerang si pemburu, akibat serangan tersebut, si pembu- \\
& ru lari tunggang langgang tidak kuat terhadap gatal-gatal yang diterimanya dan Burung \\
& Merak pun bebas (Kemendikbud, 2013:203). \\
2) & Teknologi daur ulang (recycling) dapat dimanfaatkan untuk mengolah sampah menjadi \\
& barang jadi yang bisa dimanfaatkan dalam kehidupan sehari-hari. Sampah dipungut dan \\
& dikumpulkan, misalnya, kertas, kardus, pecahan kaca, botol bekas, logam-logam, plastik, \\
& dan sebagainya. Barang-barang bekas ini bisa dikirim ke pabrik yang melakukan daur \\
& ulang bisa diolah menjadi bahan baku. Bahan baku itu dapat menghasilkan produk daur \\
& ulang seperti karton, kardus pembungkus, alat-alat dan perangkat rumah tangga dari plas- \\
& tik dan kaca (Kemendikbud, 2013:176).
\end{tabular}

Selain proses hubungan antarfenomena sebab-akibat 1-akibat 2, ternyata juga ditemukan pola baru, yaitu hubungan an- tarfenomena sebab-akibat 1-akibat 2-akibat 3 dan hubungan sebab-rangkaian akibat. Jika hubungan antarfenomena sebab-akibat 
1-akibat 2 adalah penyebab yang ada mampu menimbulkan serangkaian akibat, akibat pertama kemudian menjadi penyebab dari akibat kedua. Maka, hubungan antarfenomena sebab-akibat 1-akibat 2-akibat 3 ada sebuah akibat kedua yang menjadi penyebab dari akibat ketiga, dan seterusnya (Kurniasih dan Sani, 2014:40). Seperti dalam data 1, sebab dari penggalan teks cerita pendek tersebut adalah "Tak jauh dari tempat kejadian, segerombolan Ulat Bulu melihat kejadian ini". Setelah itu, sebab tersebut menimbulkan serangkaian akibat. Akibat pertama yang menjadi penyebab dari akibat kedua adalah "Ulat Bulu pun membantu Burung Merak untuk dibebaskan dan mereka pun menyerang si pemburu", akibat kedua yang menjadi penyebab akibat ketiga adalah "si pemburu lari tunggang langgang tidak kuat terhadap gatal-gatal yang diterimanya", dan akibat terakhir adalah "Burung Merak pun bebas". Berdasarkan temuan pola hubungan antarfenomena ini, tidak menutup kemungkinan dalam suatu kalimat atau paragraf memuat 4 rangkaian sebab-akibat atau lebih.

\section{h. Pola Proses Hubungan Antarfenomena Sebab-Rangkaian Akibat}

\begin{tabular}{ll}
\hline No & \multicolumn{1}{c}{ Data } \\
\hline 1$) \quad$ & Alam yang indah harus dicintai, dijaga, dan dilestarikan. Kecintaan pada alam itu harus \\
& selalu kita tumbuhkan kepada seluruh warga Indonesia. Selain itu, rasa cinta itu juga ha- \\
& rus terus ditanamkan agar alam Indonesia tetap menjadi paru-paru dunia yang bermanfaat \\
bagi kehidupan seluruh makhluk hidup yang hidup dari masa ke masa (Kemendikbud, \\
2013:5-6). \\
Dengan membaca buku, kita akan memperoleh pengetahuan. Oleh sebab itu, membaca \\
dapat memperbaiki kehidupan. Untuk itu, usaha peningkatan minat baca dan pemberan- \\
tasan buta aksara ini perlu didukung terus sehingga taraf hidup masyarakat akan mening- \\
kat (Kemendikbud, 2013:80-81). \\
Dengan demikian, akibat kemacetan lalu lintas pun muncul, seperti waktu yang terbuang \\
percuma. Selain itu, bahan bakar juga terbuang percuma. Kemacetan lalu lintas juga \\
dapat menyebabkan polusi udara dan suara. Bahkan, dapat mengakibatkan stress yang \\
menyerang kesehatan rohani kita (Kemendikbud, 2013:198).
\end{tabular}

Data 2 memuat penyebab "Dengan membaca buku" dan menimbulkan beberapa akibat. Ada tiga akibat yang disebabkan karena membaca buku. Akibat pertama "kita akan memperoleh pengetahuan", akibat kedua "membaca dapat memperbaiki kehidupan", akibat ketiga "usaha peningkatan minat baca dan pemberantasan buta aksara ini perlu didukung terus sehingga taraf hidup masyarakat akan meningkat". Berdasarkan temuan pola hubungan antarfenomena ini, tidak menutup kemungkinan dalam suatu kalimat atau paragraf memuat banyak akibat yang ditimbulkan oleh satu sebab.

Sebab dalam data 1 "Alam yang indah harus dicintai, dijaga, dan dilestarikan. Kecintaan pada alam itu harus selalu kita tumbuhkan kepada seluruh warga Indonesia. Selain itu, rasa cinta itu juga harus terus ditanamkan". Akibat yang pertama yaitu
"Alam Indonesia menjadi paru-paru dunia", akibat lainnya "yang bermanfaat bagi kehidupan seluruh makhluk hidup yang hidup dari masa ke masa". Sebab dalam data 3 "akibat kemacetan lalu lintas pun muncul", kemudian akibat yang ditimbulkan dari kemacetan lalu lintas itu adalah "seperti waktu yang terbuang percuma", "bahan bakar juga terbuang percuma", "polusi udara dan suara", dan "stress yang menyerang kesehatan rohani kita".

\section{Simpulan}

Berdasarkan paparan data dan hasil penelitian, ditemukan 47 wujud penalaran dalam berbagi bentuk penalaran. Empat puluh empat data yang dianalisis terdapat 47 pola penalaran, hal ini dikarenakan dalam satu data termuat 2-3 pola penalaran. Keem- 
pat puluh tujud wujud pola penalaran yang ditemukan berupa proses menalar deduktif, analogi atau analisis induktif, analogi deduktif, proses hubungan antar fenomena sebab-akibat, akibat-sebab, dan sebab-aki- bat 1-akibat 2. Bahkan ditemukan pola baru yaitu hubungan sebab-akibat 1-akibat 2-akibat 3, hubungan sebab-rangkaian akibat yang merupakan pengembangan dari hubungan sebab-akibat.

\section{Daftar Pustaka}

Febriani, Cholidia dan Abdul Haris Rosyidi. 2013. "Identifikasi Penalaran Induktif Siswa dalam Memecahkan Masalah Matematika". MATHEdunesa, Vol. 2 No 1: 1-6.

Gulo, W. 2008. Strategi Belajar Mengajar. Jakarta: Grasindo.

Ibrahim, R dan Nana Syaodih Sukmadinata. 2003. Perencanaan Pengajaran. Jakarta: Rineka Cipta.

Jalaluddin. 2013. Filsafat Ilmu Pengetahuan. Jakarta: Rajawali Pers.

Kementerian Pendidikan dan Kebudayaan. 2013. Bahasa Indonesia: Wahana Pengetahuan. Jakarta: Kementerian Pendidikan dan Kebudayaan.

Kurniasih, Imas dan Berlin Sani. 2014. Panduan Membuat Bahan Ajar Buku Teks Pelajaran Sesuai dengan Kurikulum 2013. Surabaya: Kata Pena.

Miles, Matthew B. dan A. Michael Huberman. 1994. Qualitative Data Analysis: Second Edition. California: SAGE Publications.

Rizam, Masyithah Maghfirah. 2015. "Penalaran dalam Artikel Rubrik Opini Surat Kabar Harian Jawa Pos". Kembara, Vol. 1 No 2: 2015-211.

Sitepu, B.P. 2012. Penulisan Buku Teks Pelajaran. Bandung: Remaja Rosdakarya.

Soleymanpour, Javad dan Servin Kiadaliri. 2014. "Analysis of Social Sciences Textbook in Fourth and Fifth Grade of Elementary Schools Based on Integrated Thinking Skills". Arabian Journal of Business and Management Review (Oman Chapter), Vol. 4 No 5: 13-22.

Sugiyono. 2010. Metode Penelitian Pendidikan: Pendekatan Kuantitatif, Kualitatif, dan $R \& D$. Bandung: Alfabeta.

Sukmadinata, Nana Syaodih. 2015. Metode Penelitian Pendidikan. Bandung: Remaja Rosdakarya.

Suriasumantri, Jujun S. 2010. Filsafat Ilmu: Sebuah Pengantar Populer. Jakarta: Pustaka Sinar Harapan.

Waldi, Juli dkk. 2014. "Analisis Penalaran Induktif Dalam Karangan Argumentasi Siswa Kelas X Sma Negeri 1 Linggo Sari Baganti Kabupaten Pesisir Selatan”. Jurnal Wisuda, Vol. 4 No 2: 1-6. 